Koller, Bálint and Alexander Maxwell. "Pilot Course or Flying University? A University Course on Hungarian Language and History Taught in Wellington, New Zealand." Hungarian Cultural Studies. e-Journal of the American Hungarian Educators Association, Volume 6 (2013): http://ahea.pitt.edu DOI: 10.5195/ahea.2013.119

\title{
Pilot Course or Flying University? A University Course on Hungarian Language and History Taught in Wellington, New Zealand
}

\section{Bálint Koller and Alexander Maxwell}

\begin{abstract}
The authors, a historian and a language-learning expert, recently devised an introduction to Hungarian history, language and culture for students in Wellington, New Zealand. We describe the origin and circumstances of New Zealand's Hungarian community, why we thought to develop a Hungarian language course, and how the course relates to the interests of New Zealand students. After explaining our approach to historical and linguistic components of the course, we consider the future of Hungarian studies in New Zealand.
\end{abstract}

Keywords: Hungarian cultural studies, interdisciplinary teaching, Hungarian diaspora in New Zealand, teaching Hungarian history, cultural literacy, teaching Hungarian language, communicative language learning

Biographies: Bálint Koller currently works as an advisor at the Language Learning Centre, a special division of the Library at Victoria University of Wellington, New Zealand. He earned MA degrees in English Language and Literature (with TESOL Qualification) as well as American Studies at ELTE University, Budapest. He also studied at Trinity College, Connecticut for an academic year as a recipient of the Kellner Scholarship. He is a contributing author to Prof. Zoltán Kövecses's Language, Mind, and Culture: A Practical Introduction.

Alexander Maxwell teaches history at Victoria University of Wellington, New Zealand, where he also directs the Antipodean East European Study Group. He studied physics and history for his Bachelor's degree (University of California, Davis), completed MA degrees in History (University of Wisconsin, Madison) and Nationalism Studies (Central European University, Budapest) before completing his Ph.D. in history (University of Wisconsin, Madison). He is the author of Choosing Slovakia: Slavic Hungary, the Czechoslovak Language, and Accidental Nationalism, has translated Jan Kollár's Panslav tract Reciprocity Between the Tribes and Dialects of the Slavic Nation, and edited the volumes The East-West Discourse, Symbolic Geography and its Consequences and The Comparative Approach to National Movements: Miroslav Hroch and Nationalism Studies. He is presently working on Patriots Against Fashion, a history of nationalism and clothing.

Between November 2012 and February 2013, the authors taught a university-level course on Hungarian language and culture at Victoria University in Wellington, New Zealand. To the best of our knowledge, it is the first such course offered in New Zealand's history. We believe that interdisciplinary cooperation between history and language pedagogy offered students a solid grounding in Hungarian culture. We will explain our motives for teaching the course, sketch our institutional environment, describe the course structure and content, discuss students' reactions, and contemplate the future of Hungarian studies in New Zealand. We also hope to 
Koller, Bálint and Alexander Maxwell. "Pilot Course or Flying University? A University Course on Hungarian Language and History Taught in Wellington, New Zealand." Hungarian Cultural Studies. e-Journal of the American Hungarian Educators Association, Volume 6 (2013): http://ahea.pitt.edu DOI: 10.5195/ahea.2013.119

amuse and inspire Hungarian specialists with our adventures teaching Hungarian studies in a cultural context in which Central Europe is an exotic, uncharted, and undifferentiated space. Hungarians do not form a numerous or particularly visible minority in New Zealand. While Australia acquired a population of Hungarian exiles after the 1848 revolution (Kunz a; Kunz b), the first permanent Hungarian settlers to New Zealand, mostly from Csongrád region, arrived in the 1870s (Beaglehole). The majority of New Zealand's Hungarian population, however, resulted from the ill-fated 1956 uprising, which augmented a community of 378 Hungarians with 1,117 additional refugees (Encyclopedia of New Zealand 2:631; New Zealand Department of Labour 14-15). ${ }^{1}$ Hungarian migration reduced to a trickle after the revolution, with an average only 41 Hungarians migrating to New Zealand annually between 1957 and 1970 (Mosonyi 153).

New Zealand's Hungarian community has prospered, but some have experienced difficulties maintaining their culture in Australasia. The New Zealand state, pressuring new migrants to assimilate as quickly as possible, made few concessions to old-country nostalgia. Hungarian refugees who arrived with jars of Hungarian soil, for example, found their keepsakes confiscated at immigration control because of New Zealand's strict agricultural regulations. Nor did New Zealand offer a welcoming environment for everyday Hungarian customs. One immigrant found herself having to shop at a pet store to cook mákos bejgli: "poppy seed was regarded as poisonous. The pet store was the only place where you could buy it" (Mosonyi: on assimilation policies, 126-128; on confiscated Hungarian soil, 166; on poppyseeds; 172). One should not overstate such difficulties: one satisfied immigrant ultimately concluded that of all '56 refugees, "we who have come to New Zealand are the lucky ones" (MacDonald 2). New Zealand has also attracted a further wave of voluntary immigration since the collapse of Communism. Nevertheless, the Hungarian consul in New Zealand struck a plaintive note when he declared in 2001: "there are only about 2000 of us, altogether only $0.013 \%$ of all Hungarians" (Szentirmay a; Szentirmay b).

While New Zealand makes an unlikely home for a university course on Hungarian language and culture, Wellington nevertheless offers an attractive location for any such efforts. Wellington boasts the country's most active Hungarian institutions, even if Auckland, as New Zealand's largest city, was the largest single destination for 1956 refugees. As early as 1957, a Wellington charity affiliated with the Catholic Church began publishing New Zealand's first Hungarian-language periodical, the prosaically-named News letter in the Hungarian language. The following year, Antal Oláh Tóth started a literary supplement, the Ujzélandi Magyar híradó. Additionally, the first New Zealander born to 1956 refugee parents, Maria Koveskali, was born in Wellington Public Hospital (The Evening Post 8). The present community newsletter, the Magyar szó, also based in Wellington, is affiliated with the Hungarian consul. Auckland, Christchurch, Hamilton, and Dunedin all have Hungarian clubs, but none boast a newsletter or any such concrete cultural work. Wellington even boasts a monument to the Hungarian millenium in the form of a Székelykapu (Consulate-General of Hungary in New Zealand).

\footnotetext{
${ }^{1}$ The total number of refugees was somewhere between 1,068 and 1,117 persons.
} 
Koller, Bálint and Alexander Maxwell. "Pilot Course or Flying University? A University Course on Hungarian Language and History Taught in Wellington, New Zealand." Hungarian Cultural Studies. e-Journal of the American Hungarian Educators Association, Volume 6 (2013): http://ahea.pitt.edu DOI: 10.5195/ahea.2013.119

Despite Wellington's significance to the Hungarian community of New Zealand, our course catered neither to nostalgic refugees nor their descendants. One student was German, but the rest were New Zealanders without any Hungarian heritage. How did students lacking Hungarian ancestry come to take an interest in Hungarian language and culture? Put another way, why would New Zealand benefit from its citizens acquiring expertise in Hungarian language and culture? We suggest that the concept of cultural literacy offers an answer to both questions.

All countries require cultural expertise to compete successfully in an age of globalization: we must understand each other to engage with and benefit from each other. A multilingual and cosmopolitan workforce helps a country react to new crises and opportunities. Admittedly, some forms of linguistic and cultural expertise appear to offer more tangible rewards than others. The extraordinary status of English as a global language gives it a unique significance, but New Zealand university students already speak English. China's rise would seem to make Chinese expertise attractive, and in fact our institution is presently pouring a lot of resources into the teaching of Chinese. Nevertheless, all cultural expertise is particular: knowledge of Chinese does not facilitate relations with Hungary, just as knowledge of Hungarian does not facilitate relations with China, and just as neither Chinese nor Hungarian, furthermore, would particularly help in Brazil, France, Iran, etc. Since economic opportunities and political crises are unpredictable and global, a society does well to cultivate a breadth of expertise.

Cultural capital in a new language also benefits the student as an individual. Cultural knowledge generally, and multilingualism in particular, creates rewarding career opportunities if students can attain a certain level of mastery. Familiarity with the languages and cultures of East Central Europe might be a niche market, but niche markets can provide a good living. Indeed, learning a "less commonly taught" language might, in the long run, prove more beneficial than learning a widely-studied language such as Spanish, French or Chinese: fluent speakers of widely-taught languages may have more professional opportunities, but also face stiffer competition for those opportunities. East-Central Europe has a lot to offer: let individuals and institutions follow their preferences. A Yiddish anecdote describes a shtetl where villagers marked a particular event by tying a white horse to a fencepost. "Why a horse, and why a white one? Had they tied up a black ox, the same question would remain - they tied up a white horse: why not a white horse?" (Olsvanger 112-113) Students should study a foreign language, any foreign language: why not Hungarian?

Our emphasis on multilingualism and cosmopolitanism predisposes us to support all forms of language learning, but the immediate inspiration for our particular course on Hungarian language and culture arose from an unusually dedicated group of history students. The students in question were doing their "honours degree," a certification that has few exact counterparts outside of New Zealand and may require a brief explanation. A New Zealand honours degree is a one-year supplement to the New Zealand Bachelor's degree. It demands more advanced work than a Bachelor's and is a prerequisite for admission to a Master's programme. New Zealand MA degrees demand no coursework but only a 40,000 word thesis, and so honours courses are the most advanced courses taught from a syllabus. Faculty usually design honours courses around their research interests and often recruit future Master's students from their honours 
Koller, Bálint and Alexander Maxwell. "Pilot Course or Flying University? A University Course on Hungarian Language and History Taught in Wellington, New Zealand." Hungarian Cultural Studies. e-Journal of the American Hungarian Educators Association, Volume 6 (2013): http://ahea.pitt.edu DOI: 10.5195/ahea.2013.119

cohorts. Indeed, a "summer scholarship" scheme encourages honours students by providing a chance to collaborate with a professor.

Victoria University's "History 448: National Awakening in Eastern Europe" is the only honours course devoted to East-Central Europe in all of New Zealand. ${ }^{2}$ Course readings cover nationalism theory, Czech history, and Hungarian history in roughly equal thirds. The course divides students into "team Czech" and "team Hungary" for group presentations in the hope that team work will foster collaboration between students. Students choose to write their papers on either Czech nationalism or Hungarian nationalism. It so happened that the 2012 iteration of the course acquired a strongly Hungarian flavour when "team Hungary" attracted unusually keen students.

We initially designed our summer Hungarian course with History 448 students in mind. None spoke any Hungarian, but one student had spent some time in Transylvania and understood Romanian well enough to read the Gazeta de Transilvania in its archaic partly Latin, partly Cyrillic typeface. Another spoke German. Another student, though monolingual, demonstrated the depth of his interest in Central Europe by laboriously researching primary sources in German and Hungarian with the help of online translation software! Linguistic skills are a necessary precondition for serious research in Central European history. Not even the most enthusiastic student can acquire advanced reading knowledge in even the most intensive summer course, yet the pedagogical imperative encourages faculty to support enthusiastic students, rather than discourage ambitions as unobtainable. For budding historians, furthermore, even rudimentary skills have value. For example, Google Translate, at the time of writing, understands the word nöegylet ('a women's association'), but neither nöegylettel nor nöegyletnek (respectively 'with' or 'to' a women's association), suggesting that even a basic understanding of grammatical structures would help a dedicated researcher disassemble compound words. Even a part-time summer language course, so our thinking went, might benefit history students.

When we proposed the idea of a summer Hungarian class to 448 students, they responded with enthusiasm. Indeed, our Romanian-speaking student even recruited her boyfriend to the summer course; the two are planning to visit Hungary during their "overseas experience," an established right of passage for young New Zealanders (Bell 143-158; Wilson, Fisher and Moore 159-175). We also attracted interest from a faculty member in the German programme, a connoisseur of exotic grammars who has been known to study Sanskrit in her spare time.

We developed an interdisciplinary course drawing on our respective expertise. While neither of us were hired for our Hungarian knowledge and the course did not "count" toward our official employment responsibilities, we anticipated personal satisfaction from sharing our knowledge and affection for Hungarian culture with interested students. However, we also had professional motives to devise the course related to our institutional circumstances.

Maxwell was hired to teach "modern Europe," and while he has considerable freedom to design his courses, in practice he teaches German and Soviet history to attract large student numbers. Giving lectures specifically devoted to Hungary integrated his academic research into his teaching, an outcome both personally satisfying and in accordance with much pedagogical

\footnotetext{
${ }^{2}$ Milenko Petrovic's course "The Rise and Fall of Soviet Domination in Eastern Europe," taught at the University of Canterbury in Christchurch, caters to second-year students.
} 
Koller, Bálint and Alexander Maxwell. "Pilot Course or Flying University? A University Course on Hungarian Language and History Taught in Wellington, New Zealand." Hungarian Cultural Studies. e-Journal of the American Hungarian Educators Association, Volume 6 (2013): http://ahea.pitt.edu DOI: 10.5195/ahea.2013.119

thinking (Jenkins; Brew 3-18; Barnett). The founder and director of the "Antipodean East European Study Group," furthermore, thought that a course on Hungarian language and culture would promote broader professional ambitions to promote East-Central European studies in New Zealand.

Koller works for the Language Learning Centre (LLC), a specialized branch of the University Library intended to support the teaching and learning of languages. No fewer than four different schools are involved with language teaching at our institution: the School of Languages and Cultures, the School of Linguistics and Applied Language Studies, Te Kawa a Māui (Māori studies), and Te Va'aomanū Pasifika (Pacific Studies). Koller works with all four schools to maintain a collection of print and multimedia resources for independent study. He also provides informal advice on language learning to students. A native Hungarian with a Master's in English Language and Literature and American Studies with TESOL Qualification, Koller found designing and teaching a course about his native language an irresistible opportunity for trying out various approaches and techniques in an actual classroom.

We organized the course without formal institutional backing. Even had we wanted to seek formal approval, we lacked the time. Our university schedules classes about a year in advance and new courses undergo extensive vetting at a faculty board. All syllabi, furthermore, undergo a time-consuming and pettifogging review process. We wrote our first syllabus draft on 13 September and started teaching on 1 November. We used the university's audio-visual equipment as found in empty classrooms, ordered textbooks through the Language Learning Centre acquisitions budget, and persuaded the Centre for Academic Development to process course and teacher evaluation forms. (On a scale running from 1 to 5, Koller scored a perfect 1.0, Maxwell 1.5, and the course as a whole 1.7). Our immediate supervisors nevertheless seemed alarmed when informed of our initiative and warned us not to tell too many people what we had done. One mid-level administrator praised the course itself, but advised us to hold any future courses off campus; for example, "in a pub."

While we had vaguely hoped our supervisors would commend our proactive zeal, we do not regret volunteering our time. The official centennial history of our university suggests that over the course of its history "languages had been introduced because there were staff who were willing and able to teach them" (Barrowman 288). We feel we have upheld the university's finer traditions by being willing and able.

The course structure reflected our diverse expertise. The 12-week course divided into two parts. Maxwell gave history/culture lectures, and Koller led interactive language/culture discussion sessions. Both halves of the course enjoyed regular attendance, though one student opted to attend only the language/culture sessions.

The history/culture sessions, one day a week, ran roughly chronologically. Lectures mostly coincided with traditional historiographic divisions of Hungarian history, but neglected medieval history to emphasize the nineteenth and twentieth centuries. The lectures theoretically lasted an hour, but often lasted longer since there was no pressure to keep strict timing. The history/culture sessions mostly took a lecture format, though student questions often led to discussion or digressions.

Several history/culture lectures acquired additional idiosyncratic themes related to Maxwell's personal research on nineteenth-century Hungarian nationalism. The third lecture on the Reform Era (1825-1848) linked the broader narrative of Hungarian history to the national symbolism attached to tobacco, research on which has been previously published in this journal (Maxwell c). The fourth lecture viewed the 1848-49 Revolution in part through the ethnic 
Koller, Bálint and Alexander Maxwell. "Pilot Course or Flying University? A University Course on Hungarian Language and History Taught in Wellington, New Zealand." Hungarian Cultural Studies. e-Journal of the American Hungarian Educators Association, Volume 6 (2013): http://ahea.pitt.edu DOI: 10.5195/ahea.2013.119

connotations of alcoholic beverages, the subject of an on-going if as yet unpublished research project. The fifth lecture discussed the 1867 Kiegyezés ('Ausgleich') and the Dual Monarchy from the perspective of Hungary's Slavic intelligentsias, which featured prominently in Maxwell's first book (Maxwell b). Lectures on the twentieth-century, lacking any such direct link to faculty research interests, had less idiosyncratic and more traditional narratives.

The second history/culture lecture adopted a linguistic/sociological approach. It introduced students to Rovásírás (the Hungarian rune alphabet) and the reactionary nationalist subculture promoting it in contemporary Hungary; Maxwell once published on this subject (Maxwell a). Uniquely for the history part of the course, the Rovásírás lecture included hands-on reading and writing practice. Maxwell had spent four years teaching ESL before beginning his graduate training as a historian and thus enjoyed a rare opportunity to exercise long-dormant language-teaching skills.

The lectures were delivered with highly visual PowerPoint presentations. Slides never contained bullet points, but instead showed works of art, maps, primary source documents (e.g. propaganda posters or political cartoons), photographs of important landmarks, and so forth. A series of ten slides about the 1861 February Patent, for example, contained scans of the original document with various passages highlighted (slides 1-2: Wikicommons), a political cartoon from the Budapest satirical journal Bolond Miksa depicting German and Hungarian reaction to the patent (3-4: Bolond Miksa 12), ${ }^{3}$ two additional scans from original document with further passages highlighted (5-6), a list of the Reichsrat seats assigned to each Habsburg crownland (7), a lengthy passage from Ferenc Deák justifying the Hungarian boycott (8-9), and a political cartoon from the Prague satrical journal Humoristické listy criticizing Deák's intransigence (10: Humoristické listy 99). Most images were located online, but some were acquired during a faculty research at Budapest's Egyetemi Könyvtár. The lectures averaged just over 100 slides per lecture. Some slides were copied from preexisting course lectures, but constructing such intensively illustrated lectures nevertheless required a considerable time commitment.

Seven of the history/culture sessions consisted of a formal lecture, and the remainder introduced students to iconic Hungarian films. We started with the 1999 German-Hungarian coproduction Szomorú vasárnap / Ein Lied von Liebe und Tod ('Gloomy Sunday: A Song of Love and Death'), a film which incidentally enjoyed some popularity when released in New Zealand. The movie captures the ambience of Budapest in the 1930s, but also introduced students to an iconic Hungarian song which, in the popular imagination, expresses the quintessential sadness supposedly lying at the core of the Hungarian national psyche. We next showed Péter Bacsó's 1969 A tanú ('The Witness', also known as 'Without A Trace'), partly because it complemented the previous week's lecture on Communist Hungary, and partly because Maxwell had fond memories of watching the film as a graduate student. A tanú also contributed to the language/culture agenda, since several famous lines from the film have become Hungarian idioms. We finished with Gábor Herendi's 2004 Magyar vándor ('Hungarian Wanderer'), a film which, we hoped, provided students with so many opportunities to test their ability to recognize key images or cultural tropes from Hungarian culture. Alas, students did not respond to this final

\footnotetext{
${ }^{3}$ The cartoon has two rectangular panels; each received its own slide.
} 
Koller, Bálint and Alexander Maxwell. "Pilot Course or Flying University? A University Course on Hungarian Language and History Taught in Wellington, New Zealand." Hungarian Cultural Studies. e-Journal of the American Hungarian Educators Association, Volume 6 (2013): http://ahea.pitt.edu DOI: 10.5195/ahea.2013.119

film as we had hoped. They found it "weird" and struggled to catch the cultural references. Perhaps the film would have better served more advanced students.

The language/culture sessions took place for two hours a week. They consisted of introductory language classes, supplemented with cultural content. We aimed to give students a basic introduction to Hungarian language and culture by providing a grasp of the logic of the grammar (especially vis-à-vis English). Koller emphasized listening and speaking over reading or writing; pair work and group work dominated classroom interaction. Discussions emphasized everyday situations, such as introductions, asking about other people's preferences, restaurants, and similar social situations. It emerged, for example that both students and faculty shared a strong interest in Hungarian cuisine: the topic quickly became a major theme in course discussions.

While all students attending the history/culture component had a basic background in Central European history, students in the language/culture component varied considerably in their linguistic skills. The German faculty member, as a professional language teacher and experienced language learner, progressed very rapidly; we gave her excerpts from a detailoriented descriptive grammar to maintain her interest. Two other students had significant experience with other languages (Romanian and German). The remaining students had, in essence, their first experience with a foreign language while studying Hungarian. One keen student, it transpired, could neither define nor recognize a verb. Teaching to a class with such varying abilities posed pedagogical challenges.

Mária and Ferenc Sántha's textbook PONS Beginners' Course Hungarian, with its accompanying audio material, formed the backbone of the language/culture component, though supplementary language exercises were improvised as the course progressed. The methodological approach of Sántha's coursebook coincided with Koller's language-teaching preferences; namely, to maximize active student participation and minimise frontal instruction. Many activities allowed students to discover linguistic patterns for themselves by inferring meaning from context and building on existing knowledge. To explain new grammar points, for example, the Sántha coursebook often uses sample sentences containing Hungarian words of international origin, such as pingvin, darwinizmus, mentális problémák, or szendvics. Familiar words reduced the cognitive load on the students already grappling with unfamiliar grammatical constructions. They also enabled light moments of recognition, particularly with words such as dzsessz, diszkó or sztriptiz (Sántha 18, 46). The use of such words helped students build their vocabularies, a task Anglophones may find more challenging with Hungarian than with other European languages.

The Sántha coursebook also offered several opportunities for integrating elements of the recurring culinary theme culture into the classroom. For example, a lesson about conversational skills in a retail environment featured pictures of various cakes typically available at a cukrászda, including dobostorta and Eszterházy-torta (Sántha 31). In class, students practised the sentence structure for making requests, and for homework they researched the characteristics, origins, and cultural significance of such dishes. The students seemed to enjoy these mini-research tasks. One student found the dessert recipes sufficiently inspiring to try her hand at making rigó jancsi for the class; the results filled both students and instructors with delight. In another meeting before a hot summer's 'weekend, students received an article on the origins and names of different types of fröcss ('spritzer'). Part of their homework was to have one.

In an effort to reduce teacher talking time and boost active student participation, we occasionally encouraged students to take the floor and teach each other. During a review session 
Koller, Bálint and Alexander Maxwell. "Pilot Course or Flying University? A University Course on Hungarian Language and History Taught in Wellington, New Zealand." Hungarian Cultural Studies. e-Journal of the American Hungarian Educators Association, Volume 6 (2013): http://ahea.pitt.edu DOI: 10.5195/ahea.2013.119

before a test, for example, each student was asked to pick a language point and explain it to the rest of the class at the whiteboard. While initially timid, the students quickly got used to "being on the other side" and even fielded questions from the rest of the group. Having to clarify a grammatical structure to others drove students to internalize the relevant content. It also gave the other students an alternative style or approach to explaining a language point.

Students also participated in simulated communicative scenarios with the aim of (re)producing as much spoken Hungarian as possible, even without a deep understanding of all grammatical rules. One exercise asked students to find various locations on a map of Hungary, determine the easiest route between two points, calculate the distances, and announce the road numbers in Hungarian. On another occasion, after an introduction to the relevant vocabulary, they used the Útvonaltervezés ('route planner'), available on the Budapest Transport Centre's homepage (Budapesti Közlekedési Központ). ${ }^{4}$ Such navigation exercises engaged students with current, unmodified artefacts from the target culture; namely, a map of Hungary and a Hungarian website.

In an effort to infuse language with culture even at the simplest levels, linguistic exercises were designed to subtly or explicitly incorporate cultural content wherever possible. For example, students practiced their numbers by counting the squares on Rubik's cubes, or by reading aloud key historical dates (e.g. 1526, 1848). Students practiced colours partly by learning the traditional paintwork on Budapest's public transport vehicles: yellow trams, blue buses, red trolleybuses, and green trains (sárga villamos, kék autóbusz, piros troli, zöld HÉV).

Supplementary material introduced students to key concepts and cultural artefacts that inform the mentality, patriotism, and everyday experiences of contemporary Hungarians. We exposed students to traditional hungarikumok ('Hungariana'), including paprika, lángos, túró rudi, and folk embroidery, but also to more modern artefacts such as the Malév jingle and contemporary urban slang. One exercise asked students to identify the folk motifs and associated regions depicted on Hungarian postage stamps: they located the relevant region with the help of a map and placed the stamp on an outline map of Hungary.

Music also combined language learning and cultural content. Cheeky folk songs, songs from musicals, and Hungarian rap music complemented and contextualized the linguistic foci of language lessons. For example, a 1995 song by the Animal Cannibals, "Ülünk a vonaton ('We're Sitting on the Train')," illustrated Hungarian word order in verb + location noun combinations. The rhythm and repetitive quality of the song reinforced the target grammatical structure; practice and repetition hopefully made the language material stick. A 1985 song by the band KFT “Afrika [Africa]", featured several instances of plural nouns (e.g. szavannák), nouns with object markers (e.g. Zimbabwét), or both (e.g. lányokat). The song also features several nouns that could be mistaken for either by virtue of their final consonants (e.g. élvezet, fizetek). The students listened to the song and, with the help of a transcription and translation, had to identify the meaning and syntactic position of each words. The exercises thus practiced grammatical structure, but also celebrated Hungarian musical creativity.

Voice-recording exercises encouraged self-monitoring and self-improvement. One assignment asked students to record a brief conversation about giving directions. The paired

\footnotetext{
${ }^{4}$ See the "Útvonaltervezés" feature on the lower right of the page.
} 
Koller, Bálint and Alexander Maxwell. "Pilot Course or Flying University? A University Course on Hungarian Language and History Taught in Wellington, New Zealand." Hungarian Cultural Studies. e-Journal of the American Hungarian Educators Association, Volume 6 (2013): http://ahea.pitt.edu DOI: 10.5195/ahea.2013.119

nature of the exercise obliged students to arrange a meeting after class, which helped foster a sense of solidarity. Another voice-recording exercise, this time involving the entire class, drew inspiration from the famous patriotic poem by Miklós Radnóti, "Nem tudhatom" ('I cannot know') (Dus 236). The poem was divided into five natural chunks; each student chose a section to record after reading an English translation (Hargittai). The separate tracks were then combined and made available as the entire poem. The exercise also strengthened group cohesion and created a sense of collective achievement. It also exposed students to a quiet but powerful expression of Hungarian patriotism, laden with themes and imagery easily accessible at a personal level, but also deeply significant in Hungarian culture. Students specifically requested additional voice-recording tasks, evidently finding them both challenging and enjoyable.

A subtler level of culture, the areas of courtesy and politeness were also routinely explored throughout the course. The use of diminutives as terms of endearment [e.g. Kevin > Kevinke "little Kevin" > Kevinkém "my little Kevin"], the ubiquitous habit of saying jó étvágyat [bon appétit] before a meal, or the prolific use of the greeting csókolom as a sign of respect for seniority all provided teachable moments in cultural literacy and cross-cultural understanding. Consider, for example, the grammatically awkward yet ubiquitous use of tetszik as a helping verb when addressing respected seniors. We examined typical scenarios in which the tetszik structure would be appropriate. During a discussion of the terms bácsi ('uncle') and néni ('aunt'), which frequently accompany the tetszik style, one student usefully compared Hungarian usage to the similar Māori custom of calling any respected elder "uncle" or "auntie."

Both the language/culture and the history/culture segments of the course explicitly situated Hungarian culture within a larger, overarching East-Central European context. We encouraged students to share their existing cultural and historical knowledge with the class, whether it was directly related to Hungarian culture or not. The group as a whole brought an immense wealth of pre-existing knowledge to the table. The German language tutor, originally from Bavaria and fluent in Russian, proved particularly conversant with Central European culture, often drawing useful parallels with German. The student with Romanian expertise shared similar moments of recognition. Drawing such connections situated the unique features of the Hungarian experience within the context of neighboring cultures.

In a final effort to make Hungarian relevant to the students' own culture, classroom activities let students to discuss New Zealand place names, celebrities, and cultural icons. Using the Hungarian language to discuss the Wellington cable car or the All Blacks gave student a chance to integrate Hungarian with their own cultural references. We hoped that making the language relevant to their lives would increase their motivation for further study. We are proud to report that one student has signed up for a further Hungarian language course taught by the Hungarian consul.

We could only achieve so much with an unofficial course for which students paid no tuition, earned no transcript credit, and received no grades. Instructors teaching as volunteers have finite leverage over students. Students proved willing to complete homework for the language/culture sessions, but we had to ensure the tasks were short and enjoyable. We did not dare to assign any homework for the history/culture sessions, but a hand-out with the rovásírás alphabet inspired a charming Christmas card. We both administered informal quizzes as a pedagogical strategy, but had no real ability to reward or punish.

Transforming the course into something more formal and effective would probably require institutional support. While the university's strategic plan proclaims the goal of "engaging with local, national and international communities" and promoting "the deeper 
Koller, Bálint and Alexander Maxwell. "Pilot Course or Flying University? A University Course on Hungarian Language and History Taught in Wellington, New Zealand." Hungarian Cultural Studies. e-Journal of the American Hungarian Educators Association, Volume 6 (2013): http://ahea.pitt.edu DOI: 10.5195/ahea.2013.119

understanding of history and culture that builds a knowledgeable and better society" (Council of Victoria University of Wellington 2, 23, 24), in practice the administration has chosen to prioritize Asia over Europe: in the School of Languages and Cultures, Chinese is showered with resources while German is starved. In 2000, the university also discontinued the teaching of Russian, despite strong institutional traditions in Slavic studies. Victoria faculty once offered courses in Bulgarian, and originally founded the New Zealand Journal of Slavonic Studies, since relocated to Christchurch (Barrowman 284-286, 289).

Members of New Zealand's Hungarian community might theoretically be interested in supporting the course, since community leaders have long expressed concern about the decline of Hungarian competency in subsequent generations. The newsletter of New Zealand's Hungarian community, the Magyar Szó, periodically advertises Hungarian language classes abroad (Hellyer 27; Balassi Bálint 45). Nevertheless, Imre Gyöngyös, a 1956 refugee, poetically lamented on its pages that "our little Hungarian language evaporates like a light dew" in New Zealand (Gyöngyös 18). Wellington Hungarians have taken concrete steps to preserve and promote Hungarian culture. The founding editor of Magyar Szó, Paul Szentirmay, perhaps drawing on the library science training he acquired in New Zealand after arriving from Hungary, devoted his later years to a "Hungarianness Research Programme," conducting oral histories of New Zealand Hungarians. The results were to be deposited at both the National Library of New Zealand in Wellington and the Országos Széchényi Könyvtár in Budapest (K. Szentirmay 9). His daughter Klára Szentirmay, the present editor of Magyar Szó, has continued gathering oral histories, and herself regularly teaches evening classes in Hungarian. She kindly offered to advertise future iterations of our course through the consular newsletter and, in her capacity as Hungarian consul, hosted the class for home-cooked paprikás csirke ('paprika chicken') after the class ended. She also invited students to contribute a blurb about themselves for a forthcoming issue of Magyar Szó. Perhaps future iterations of the course will attract further support.

More formal Hungarian courses might also emerge from the logic of history teaching. History 448 will be offered again; future students may develop a similar enthusiasm for a deeper study of Hungarian history, language, and culture. Perhaps the course could also be offered as a night class through the university's continuing education programme, or in some other guise. A pilot course might foreshadow future offerings in Hungarian language and culture, and in East European studies generally.

If support for continuing our course fails to materialize, however, we console ourselves with the thought that our course carried on a tradition from Poland, Hungary's traditional ally: the illustrious uniwersytet latajacy, the 'flying university.' When Tsarist or Soviet tyranny proscribed the free expression of Polish scholarship, patriots defied hostile authorities and met in private homes to cultivate education and scholarship in the Polish language (on the nineteenthcentury Uniwersytet Latający, see Davis 2:172 and Stegmann 73-79; for the twentieth-century, see Buczynska-Garewicz 20-34 and Pszenicki 19-22). Of course, we do not presume to equate our efforts with Polish independence struggles. Our efforts face bureaucratic inertia and indifference, not active persecution. Nevertheless we draw some inspiration from the memory of passionate intellectuals who spontaneously organized lectures according to their own ideas, teaching students more eager for knowledge than qualifications, in defiance of all obstacles. 


\section{Works Cited}

Balassi Bálint Magyar Kulturális Intézet. 2010. “Call for Scholarship Applications.” Magyar Szó [Hungarian Word] 100: 45.

Barnett, Ronald, ed. 2005. Reshaping the University: New Relationships between Research, Scholarship and Teaching. Maidenhead: McGraw-Hill.

Barrowman, Rachel. 1999. Victoria University of Wellington, 1899-1999: A History. Wellington: Victoria University Press.

Beaglehole, Ann. "Hungarians: Immigration before 1956: Navvies and exiles." Te Ara: Encyclopedia of New Zealand. Accessed 4 March 2009. $<$ http://www.teara.govt.nz/en/hungarians/1>.

Bell, Claudia. August 2002. "The Big 'OE': Young New Zealand Travelers as Secular Pilgrims." Tourist Studies 2.2: 143-158.

Bolond Miksa. 1861. "Élő Telegrafok [Living Telegraphs]." 2.3: 12.

Brew, Angela. 2003. "Teaching and Research: New Relationships and their Implications for Inquiry-Based Teaching and Learning in Higher Education." Higher Education Research and Development, 22: 3-18.

Buczynska-Garewicz, Hanna. 1985. "The Flying University in Poland, 1978-1980.” Harvard Educational Review 55.1: 20-34.

Budapesti Közlekedési Központ [Center for Budapest Transport]. "Útvonaltervezés [route planning].” Accessed 21 January 2013. <http://www.bkk.hu>

Consulate-General of Hungary in New Zealand. Magyar Millennium Park. Accessed 23 January 2013. 〈http://hungarianconsulate.co.nz/mmp_en.html>

Council of Victoria University of Wellington. 2008. "Strategic Plan 2009-2014." $<$ http://www.victoria.ac.nz.home/about/newspubs/publications/StrategicPlanA5booklet.p df $>$

Davies, Norman. 1982. God's Playground: A History of Poland. New York: Columbia University Press.

Dus, János, ed. 1995. Válogatás Ady Endre, József Attila, Radnóti Miklós müveiböl [Selected poems of Endre Ady, Attila József, and Miklós Radnóti]. Budapest: Corpus.

Encyclopedia of New Zealand. 1966. "National Groups: Hungarians." Wellington: Government Printer.

The Evening Post. 4 January 1957. "Hungarian Refugees Now Have a Kiwi." 8. Reprinted in 2006: Magyar Szó 85: 15.

Gyöngyös, Imre. 2008. "Új-Zéland-i Magyar ballada [New Zealand-Hungarian Ballad]." Gémes, Anikó. "Emberek \& Történetek [People and Stories]." Magyar Szó 93: 18.

Hargittai, Eszter. 30 April 2004. "Out of the Crooked Timber of Humanity, No Straight Thing was Ever Made.” Accessed 10 December 2012. <http://crookedtimber.org/2004/04/30/nem-tudhatom/>

Hellyer, Zsófia. 2006. "My year at 'the Balassi'.” Magyar Szó 85: 27.

Humoristické listy [Humorous Pages]. 1867. "Translajtánský Mojžiš [Transatlantic Moses]” 9.25: 99. 
Koller, Bálint and Alexander Maxwell. "Pilot Course or Flying University? A University Course on Hungarian Language and History Taught in Wellington, New Zealand." Hungarian Cultural Studies. e-Journal of the American Hungarian Educators Association, Volume 6 (2013): http://ahea.pitt.edu DOI: 10.5195/ahea.2013.119

Jenkins, Alan. 2003. Reshaping Teaching in Higher Education: Linking Teaching with Research. London: Routledge.

Kunz, Egon a. 1969. Blood and Gold: Hungarians in Australia. Melbourne: Cheshire.

Kunz, Egon b. 1985. The Hungarians in Australia. Melbourne: Educa Press.

MacDonald, Iain. 17 July 1982. "A Placid Melting Pot.” New Zealand Herald: 2.

Maxwell, Alexander a. 2004. "Contemporary Hungarian Rune Writing: Linguistic Nationalism within a Homogenous Nation." Anthropos 99: 161-175.

Maxwell, Alexander b. 2009. Choosing Slovakia: Slavic Hungary, the Czech Language and Unintended Nationalism. London: I.B. Tauris.

Maxwell, Alexander c. 2012. "Tobacco as Cultural Signifier: A Cultural History of Masculinity and Nationality in Habsburg Hungary." AHEA: E-Journal of the American Hungarian Educators' Association, 5: 1-19.

Mosonyi, Attila. 1997. "Distant Refuge: Politics and Immigration Experiences of Refugees of the 1956 Hungarian Revolution to Australia and New Zealand. University of Auckland: Master's thesis.

New Zealand Department of Labour. May 1957. "Refugees from Hungary." Labour and Employment Gazette, 7.2: 14-15.

Olsvanger, Immanuel. 1965 [1947]. Röyte Pomerantsen [Red Oranges], or How to Laugh in Yiddish. New York: Shocken.

Petrovic, Milenko. "The Rise and Fall of Soviet Domination in Eastern Europe." University of Canterbury. Accessed 22 January 2013.

<http://www.europe.canterbury.ac.nz/courses/pdf/226_06.pdf>.

Pszenicki, Chris. 1979. "The Flying University." Index on Censorship 8.6: 19-22.

Sántha, Mária and Ferenc Sántha. 2012. PONS Beginners ' Course Hungarian. Budapest: Klett.

Stegmann, Natali. 2000. Die Töchter der geschlagenen Helden: "Frauenfrage,” Feminismus und Frauenbewegung in Polen, 1863-1919 [The daughters of fallen heroes: the "women's question," feminism and womem's movement in Poland]. Wiesbaden: Harrassowitz.

Szentirmay, Klara. 2010. "Paul Szentirmay, founder of the Magyar Szó [Hungarian Word]." Magyar Szó 100: 8-9.

Szentirmay, Paul a. 2001. "Millennium Secret.” Magyar Szó 64.

Szentirmay, Paul b. 2007. "Millennium Secret.” Magyar Szó 88.

Wikicommons, "Category: Constitution of the Austrian Empire - Februarpatent." Accessed 21 January 2013.

<http://commons.wikimedia.org/wiki/Category:Constitution_of_the_Austrian_Empire__Februarpatent>

Wilson, Jude, David Fisher and Kevin Moore. 2009. "Reverse Diaspora and the Evolution of a Cultural Tradition: The Case of the New Zealand 'Overseas Experience'." Mobilities 4.1: 159-175. 